\title{
Comparison of high fibre diets, basal insulin supplements, and flexible insulin treatment for non-insulin dependent (type II) diabetics poorly controlled with sulphonylureas
}

\author{
A R Scott, Y Attenborough, I Peacock, E Fletcher, W J Jeffcoate, R B Tattersall
}

Abstract

Objective-To compare high fibre diet, basal insulin supplements and a regimen of insulin four times daily in non-insulin dependent (type II) diabetic patients who were poorly controlled with sulphonylureas.

Design-Run in period lasting 2-3 months during which self monitoring of glucose concentration was taught, followed by six months on a high fibre diet, followed by six months' treatment with insulin in those patients who did not respond to the high fibre diet.

Setting-Teaching hospital diabetic clinics.

Patients - 33 patients who had had diabetes for at least two years and had haemoglobin $A_{1}$ concentrations over $10 \%$ despite receiving nearly maximum doses of oral hypoglycaemic agents. No absolute indications for treatment with insulin.

Interventions-During the high fibre diet daily fibre intake was increased by a mean of $16 \mathrm{~g}(95 \%$ confidence interval 12 to $20 \mathrm{~g}$.) Twenty five patients were then started on once daily insulin. After three months 14 patients were started on four injections of insulin daily.

Endpoint-Control of diabetes (haemoglobin $\mathbf{A}_{1}$ concentration $\leqslant 10 \%$ and fasting plasma glucose concentration $\leqslant 6 \mathrm{mmol} / \mathrm{l}$ ) or completion of six months on insulin treatment.

Measurements and main results-No change in weight, diet, or concentrations of fasting glucose or haemoglobin $A_{1}$ occurred during run in period. During high fibre diet there were no changes in haemoglobin $\mathbf{A}_{1}$ concentrations, but mean fasting glucose concentrations rose by $1.7 \mathrm{mmol} / 1(95 \%$ confidence interval 0.9 to $2.5, p<0.01$ ). With once daily insulin mean concentrations of fasting plasma glucose fell from 12.6 to $7.6 \mathrm{mmol} / \mathrm{l}(\mathrm{p}<0.001)$ and haemoglobin $A_{1}$ from $14.6 \%$ to $11.2 \%(p<0.001)$. With insulin four times daily concentrations of haemoglobin $A_{1}$ fell from $11.5 \%$ to $9.6 \%(p<0.02)$. Lipid concentrations were unchanged by high fibre diet. In patients receiving insulin the mean cholesterol concentrations fell from $7 \cdot 1$ to $6.4 \mathrm{mmol} / \mathrm{l}$ $(p<0.0001)$, high density lipoprotein concentrations rose from 1.1 to $1.29 \mathrm{mmol} / 1(p<0.01)$, and triglyceride concentrations fell from 2.67 to $1.86 \mathrm{mmol} /$ $1(p<0.05)$. Patients taking insulin gained weight and those taking it four times daily gained an average of $4 \cdot 2 \mathrm{~kg}$.

Conclusions-High fibre diets worsen control of diabetes in patients who are poorly controlled with oral hypoglycaemic agents. Maximum improvements in control of diabetes were achieved by taking insulin four times daily.

\section{Introduction}

Many patients with type II diabetes are poorly controlled when taking maximum doses of sulphonyl- ureas with or without metformin..$^{1-3}$ Such patients are usually recommended to change to insulin, although we have shown in the only prospective randomised study to date that this does not guarantee better control. ${ }^{4}$ This earlier study was criticised because the regimen of insulin once daily was not ideal and the diet, which provided $40 \%$ of energy from carbohydrate with no added fibre, was out of line with the new recommendations of national diabetes associations. ${ }^{56}$ Mann et al suggested that many of our patients could have been "rescued" by a high fibre diet," and we now report a sequential comparison of a high fibre diet, basal insulin supplements, and a regimen of insulin four times daily in type II diabetic patients who were poorly controlled with sulphonylureas.

\section{Patients, study design, and methods PATIENTS}

We chose patients who had had diabetes for at least two years and had haemoglobin $A_{1}$ concentrations over $10 \%$ even though they were receiving oral hypoglycaemic agents in near maximum doses; they had poor glycaemic control when taking tablets but did not have absolute indications for insulin (symptoms, islet cell antibodies, ketonuria, progressive weight loss, or progressive increase in haemoglobin $A_{1}$ concentration). Those whose haemoglobin $A_{1}$ had varied by more than $2 \%$ or who had lost more than $2 \mathrm{~kg}$ over the previous six months were excluded.

\section{STUDY DESIGN}

The study was divided into three parts: a run in period lasting two to three months, a high fibre diet maintained for six months, and insulin given subsequently for six months.

During the run in period self monitoring of blood glucose concentrations with reagent strips (BM 1-44; Boehringer Mannheim) was taught. It was carried out throughout the study. Seven point profiles (readings taken before and 90 minutes after each meal and at bedtime) were requested weekly; patients returned the reacted strips to us in an airtight, dessicated tube, and strips were read with a Reflolux 2 meter (Boehringer Mannheim). No new dietary advice was given during the run in period, but the dose of sulphonylureas was increased to at least $15 \mathrm{mg}$ glibenclamide (or equivalent) a day.

At the end of the run in period the patients were seen individually by a dietitian (YA), who explained that increasing the amount of fibre and carbohydrate in their diet might improve their diabetic control. Patients were given a list of foods high in fibre and asked initially to increase their intake by $10 \mathrm{~g}$ a day by eating wholemeal bread and a high fibre breakfast cereal. During the next three months three group teaching sessions were held to reinforce the principles of managing diabetes and explain the possible benefits of a diet high in fibre and low in fat. These sessions 
were backed up by menus, a cookery book, ${ }^{8}$ and cooking demonstrations. The aim was to increase fibre intake gradually to $50 \mathrm{~g}$ a day, of which $10-15 \mathrm{~g}$ should come from legumes.

Patients whose diabetes remained uncontrolled (haemoglobin $A_{1}$ concentration over $10 \%$ or fasting plasma glucose concentration over $6 \mathrm{mmol} / \mathrm{l}$ ) after six months on the high fibre diet were given an evening supplement of insulin zinc suspension (Human Ultratard; Novo, Copenhagen). Oral drugs were stopped but the high fibre diet continued. Based on the weekly blood glucose profiles the dose of insulin was increased until the fasting plasma glucose concentration was consistently below $6 \mathrm{mmol} / \mathrm{l}$. If late afternoon hyperglycaemia occurred despite a normal fasting plasma glucose concentration, the dose of insulin was split, one third being given before breakfast and two thirds in the evening.

If target blood glucose concentrations had not been reached after at least three months of supplementation with insulin zinc suspension the regimen was changed to preprandial neutral insulin injection (Human Actrapid injected with the NovoPen; Novo, Copenhagen) and insulin zinc suspension at bedtime. This was tailored to each patient through weekly telephone conversations to aim for blood glucose concentrations of $4-6.5 \mathrm{mmol} / \mathrm{l}$ before meals and $\leqslant 9 \mathrm{mmol} / 190$ minutes after meals.

\section{METHODS}

Concentrations of fasting plasma glucose, haemoglobin $A_{1}$, fasting serum cholesterol, high density lipoprotein, cholesterol, and triglycerides were measured at the end of each of the three stages. Plasma glucose concentration was measured with a BeckmanII analyser (Beckman Instruments, Fullerton, California). Haemoglobin $A_{1}$ concentration was measured on cellulose acetate membranes by mobile affinity electrophoresis. ${ }^{9}$ At the end of the run in period plasma $C$ peptide concentration was measured before and six minutes after an intravenous injection of $1 \mathrm{mg}$ glucagon (Novo, Copenhagen) by the method of Heding. ${ }^{10}$ This gave an intra-assay coefficient of variation of $4 \cdot 8 \%$ and an interassay coefficient of $\mathbf{9 \cdot 3} \%$. Serum lipid concentrations were measured with commercial kits (GPOPAP and Merckotest, Boehringer Mannheim) on completion of the study, having been frozen and stored

TABLE I-Measures of glycaemic control and weight of diabetic patients during run in period, high fibre diet, and treatment with insulin

\begin{tabular}{|c|c|c|c|c|}
\hline & $\begin{array}{l}\text { Fasting } \\
\text { plasma } \\
\text { glucose } \\
(\mathrm{mmol} / \mathrm{l})\end{array}$ & $\begin{array}{c}\text { Mean } \\
\text { blood } \\
\text { glucose }\end{array}$ & $\mathrm{HbA}_{1} \dagger$ & $\begin{array}{c}\text { Weight } \\
(\mathbf{k g})\end{array}$ \\
\hline \multirow{7}{*}{$\begin{array}{l}\text { Start of study }(n=33) \\
\text { End of run in period }(n=33) \\
\text { End of high fibre diet }(n=33) \\
\text { Start of treatment with insulin }(n=25) \\
\text { Insulin zinc suspension only }(n=25) \\
\text { Insulin zinc suspension and neutral } \\
\text { insulin injection }(n=14)\end{array}$} & $11 \cdot 1$ & & $13 \cdot 5$ & $69 \cdot 7$ \\
\hline & 10.8 & $12 \cdot 3$ & $13 \cdot 1$ & $69 \cdot 8$ \\
\hline & $12 \cdot 6 \ddagger$ & $13 \cdot 2$ & 13.9 & $70 \cdot 6$ \\
\hline & 12.6 & 13.9 & $14 \cdot 6$ & $67 \cdot 0$ \\
\hline & $7 \cdot 69$ & $11 \cdot 0 \|$ & $11 \cdot 2 \|$ & 69.85 \\
\hline & & & & \\
\hline & $7 \cdot 0$ & 7.69 & $9 \cdot 6$ & $71 \cdot 2 \|$ \\
\hline
\end{tabular}

^Mean of seven point blood glucose profiles (measured by the patients at home) over last six weeks of each treatment.

home) over last six weeks

NNormal range $5 \cdot 0-8 \cdot 5$.

$\mathrm{P}<0.01$ compared with end of run-in period.

$\$ \mathrm{P}<0.01, \| \mathrm{P}<0.001, \uparrow \mathrm{P}<0.0001$ Compared with start of treatment with insulin.

TABLE II - Analysis of food intake of patients completing run in period, high fibre diet, and treatment with insulin. Patients recorded foods eaten on five consecutive days

\begin{tabular}{|c|c|c|c|c|c|c|}
\hline & \multirow[b]{2}{*}{$\begin{array}{c}\text { Fibre } \\
\text { (g/day) }\end{array}$} & \multirow[b]{2}{*}{$\mathrm{MJ} /$ day } & \multicolumn{2}{|c|}{ Carbohydrate } & \multicolumn{2}{|c|}{ Fat } \\
\hline & & & g/day & $\begin{array}{l}\% \text { total } \\
\text { energy }\end{array}$ & g/day & $\begin{array}{l}\% \text { total } \\
\text { energy }\end{array}$ \\
\hline Start of study $(n=33)$ & 21 & $7 \cdot 78$ & 172 & 36 & 91 & 44 \\
\hline End of run in $(n=33)$ & 19 & 7.85 & 174 & 35 & 97 & 45 \\
\hline End of high fibre diet $(n=28)$ & $35^{\star \star \star \star}$ & $9 \cdot 20^{\star \star}$ & $229^{\star \star \star}$ & $40^{\star \star \star}$ & 101 & 41 \\
\hline End of treatment with insulin $(n=21)$ & $31^{\star \star \star \star}$ & $9.02 \star \star$ & $223 \star \star \star$ & $39 \star$ & 102 & 43 \\
\hline
\end{tabular}

${ }^{\star} p<0.05,{ }^{\star \star} p<0.01,{ }^{\star \star \star} p 0.001$ compared to end of run in period. at $-20^{\circ} \mathrm{C}$. The intra-assay and interassay coefficients of variation were $1.7 \%$ and $2.5 \%$ for cholesterol, $1.3 \%$ and $2 \cdot 1 \%$ for triglycerides, and $2 \cdot 5 \%$ and $4.5 \%$ for high density lipoprotein cholesterol, respectively.

Food intakes were assessed from records kept for five days (three weekdays and a weekend) at the beginning and end of the run in period, after six months on the high fibre diet, and after six months' treatment with insulin. A computer programme (Microdiet, University of Salford) was used for nutritional analysis.

Results were analysed with Student's paired $t$ test, Wilcoxon's signed rank test, and Pearson's correlation coefficient, as appropriate; $95 \%$ confidence intervals of the differences between means were calculated, and a $p$ value of $<0.05$ was regarded as significant.

\section{Results}

Thirty eight patients were recruited, of whom five withdrew in the first three months. The 33 who completed the high fibre diet were 19 men and 14 women with a mean age of 55 years (range 31-68), mean duration of diabetes 10 years (range 2-25), and mean body mass index $24.9 \mathrm{~kg} / \mathrm{m}^{2}$ (range $17 \cdot 0-33 \cdot 6$ ). Ten had an ideal body weight over $120 \% .^{1}$

\section{RUN IN PERIOD}

There was no change in body weight or concentrations of fasting plasma glucose or haemoglobin $A_{1}$ (table I). Food records (table II) confirmed a reasonably consistent intake with no significant differences between the beginning and end of the period, when 30 - of the 33 patients were taking glibenclamide $\geqslant 15 \mathrm{mg}$ daily and 13 were also taking metformin (up to $3 \mathrm{~g}$ daily).

\section{HIGH FIBRE DIET}

Five patients did not complete all food records, and analysis was based on records from 28 patients (table II). Daily fibre intake rose from $19 \mathrm{~g}$ at the end of the run in period to $35 \mathrm{~g}$ (mean increase $16 \mathrm{~g}, 95 \%$ confidence interval 12 to $20 \mathrm{~g}, \mathrm{p}<0.001$ ). Only two patients achieved the target of $50 \mathrm{~g}$ fibre-day (fig 1), and

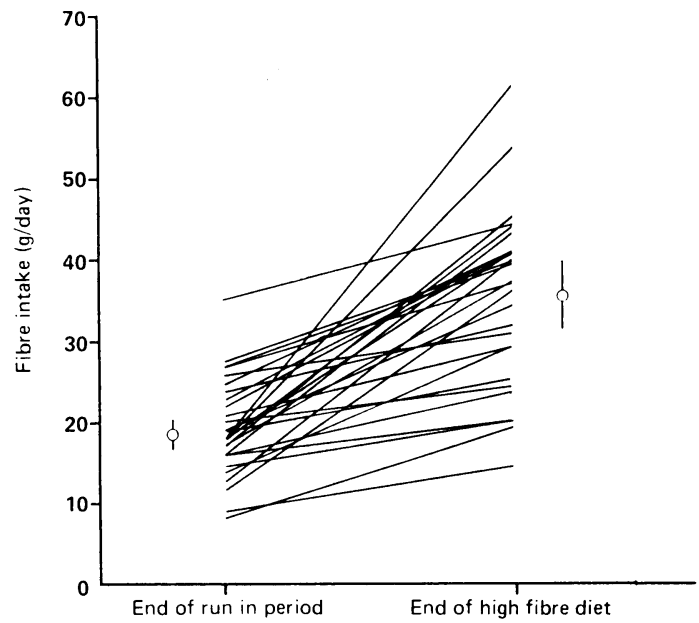

FIG 1 - Daily intake of fibre of 28 patients at end of run in period and after six months on high fibre diet. Open circles are means $(95 \%$ confidence intervals); difference is significant $(p<0.001)$

10 had an increase of $<10 \mathrm{~g} /$ day. Only one patient complained of unacceptable side effects (flatus and abdominal discomfort). Most patients included some leguminous fibre but usually only from common foods such as baked (haricot) beans and broad beans.

There was no change in haemoglobin $A_{1}$ concentration $(p>0 \cdot 1)$ (table I) and no relation between change in intake of fibre and change in haemoglobin $A_{1}$ 
concentration $(r=0.03)$, whether or not patients whose fibre intake rose by $<10 \mathrm{~g} /$ day were excluded. Fasting plasma glucose concentration deteriorated significantly, from $10.8 \mathrm{mmol} / \mathrm{l}$ at the end of the run in period to $12.6 \mathrm{mmol} / \mathrm{l}$ at the end of the period on a high fibre diet (mean increase $1.7 \mathrm{mmol} / 1$ ( $95 \%$ confidence interval 0.9 to $2.5, \mathrm{p}<0.01$ ). Fasting plasma glucose concentration rose only in patients whose intake of fibre increased by $>10 \mathrm{~g} /$ day (mean increase $2 \cdot 1$ $\mathrm{mmol} / \mathrm{l}(95 \%$ confidence interval 0.6 to $3.6, \mathrm{p}<0.01)$, and was unchanged in those whose intake increased by $<10 \mathrm{~g} /$ day (mean change $0.7 \mathrm{mmol} / \mathrm{l}$ ( $95 \%$ confidence interval -0.5 to 1.9$)$. An increased intake of fibre was accompanied by a mean increase in energy intake of $1.35 \mathrm{MJ} /$ day $(95 \%$ confidence interval 0.51 to $2 \cdot 19, \mathrm{p}<0.01$ ) (figure 2). Daily carbohydrate intake

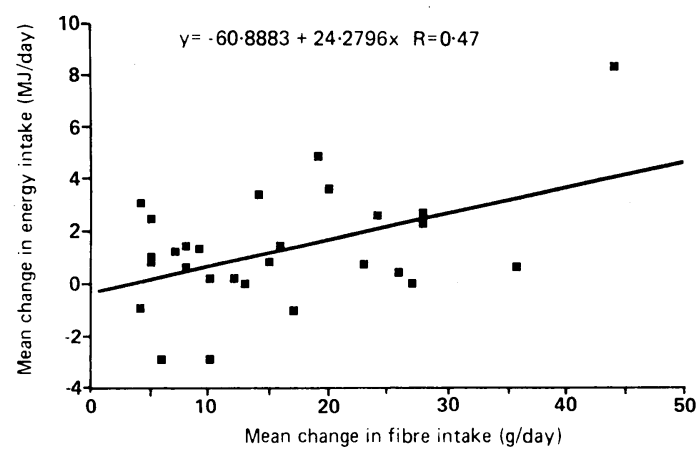

FIG 2-Mean changes in daily intake of energy related to mean changes in daily intake of fibre in 28 diabetic patients taking a high fibre diet

increased from $174 \mathrm{~g}$ to $229 \mathrm{~g}$ (mean increase $55 \mathrm{~g}, 95 \%$ confidence interval 30 to $80, \mathrm{p}<0.0001$ ) during the period on a high fibre diet and remained at the higher level during insulin treatment (table II). Carbohydrate intake averaged $35 \%$ of total energy intake during the run in period, rising to $40 \%$ during the high fibre period (mean increase $4 \%, 95 \%$ confidence interval 2 to $6, p<0.001)$. Fat intake during the run in period was $45 \%$ of total energy intake, decreasing to $41 \%$ on the high fibre diet (mean difference $-3 \cdot 6 \%, 95 \%$ confidence interval -1.9 to $-5.3, \mathrm{p}<0.0001$ ).

\section{INSULIN TREATMENT}

After six months on a high fibre diet only two patients had achieved the target concentrations of blood glucose; three others refused insulin. Of the 28 who started taking insulin zinc suspension once daily, three dropped out because of dislike of injections or intervening illness. The remaining 25 injected insulin zinc suspension in the evening, which led to noticeable improvement in fasting plasma glucose concentrations (from 12.6 to $7.6 \mathrm{mmol} / \mathrm{l}$, mean difference $-5.0 \mathrm{mmol}$, $95 \%$ confidence interval -4.6 to $-5.4, \mathrm{p}<0.0001$ ) and haemoglobin $A_{1}$ (from $14 \cdot 6 \%$ to $11 \cdot 2 \%$, mean difference $-3 \cdot 4 \%, 95 \%$ confidence interval -3.0 to $-3.8, \mathrm{p}<0.001)$. The mean total daily dose of insulin was 36 units (range 29 to 43 ); in 16 patients with late afternoon hyperglycaemia the dose was split. Only seven of the 25 patients reached the target concentration of haemoglobin $A_{1}$ of $\leqslant 10 \%$ after six months of treatment with insulin. At this stage three asked to go back to tablets (one disliked injections and two had recurrent severe nocturnal hypoglycaemia).

Fourteen of the remaining 22 patients were offered the injection device and completed a mean of 3.4 months on four injections a day (range 2-5 months). These patients had a further fall in haemoglobin $A_{1}$ concentrations, from $11.5 \%$ to $9.6 \%$ (mean difference $-1 \cdot 8 \%, 95 \%$ confidence interval $-1 \cdot 4$ to $-2 \cdot 2$, $\mathrm{p}<0.02$ ), but at the expense of more weight gain. After six months of insulin treatment they had increased their weight by a mean of $4 \cdot 2 \mathrm{~kg}(95 \%$ confidence interval 3.0 to 5.4 ) compared with weight at the end of the six months of the high fibre diet.

\section{PEPTIDE AND LIPIDS}

Mean fasting concentration of $\mathrm{C}$ peptide at the end of the run in period was $0.75 \mathrm{nmol} / \mathrm{l}$ (range $0.24-1.6$ ) and in all patients this increased after glucagon (mean increment $0.41 \mathrm{nmol} / \mathrm{l}$ (range $0.02-0.80$ ). Neither the fasting concentration of $\mathrm{C}$ peptide nor the increment predicted change in control of blood glucose concentrations while patients were taking a high fibre diet.

Concentrations of fasting serum triglycerides, total cholesterol and high density lipoprotein cholesterol were unchanged by the high fibre diet. When the patients took insulin the mean concentration of total cholesterol fell from $7 \cdot 1$ to $6.4 \mathrm{mmol} / \mathrm{l}$ (mean difference $-0.6 \mathrm{mmol} / 1,95 \%$ confidence interval -0.02 to $-1 \cdot 1$, $\mathrm{p}<0.0001$ ). Concentration of high density lipoprotein cholesterol rose from $1 \cdot 10$ to $1.29 \mathrm{nmol} / \mathrm{l}$ (mean difference $0.19 \mathrm{mmol} / \mathrm{l}, 95 \%$ confidence interval 0.08 to $0.30, \mathrm{p}<0.01)$, and triglyceride concentrations fell from 2.67 to $1.86 \mathrm{mmol} / 1$ (mean difference $-0.77 \mathrm{mmol} / \mathrm{l}, 95 \%$ confidence interval -0.08 to $-1.46, \mathrm{p}<0.05)$

\section{Discussion}

National diabetes associations now recommend diets with a substantial amount of carbohydrate and fibre and little fat to improve glycaemic control and reduce the risk factors for ischaemic heart disease. ${ }^{5612}$ In our study such a diet in typical patients with type II diabetes taking maximum doses of tablets worsened glycaemic control: fasting plasma glucose concentration increased from 10.8 to $12.6 \mathrm{mmol} / \mathrm{l}$ and concentration of haemoglobin $A_{1}$ increased from $13 \cdot 1 \%$ to $14 \cdot 6 \%$. Our results are not particularly surprising as there is considerable doubt that simply increasing the amount of carbohydrate in the diet of diabetic patients will by itself improve metabolic control. Reaven and colleagues point out that most studies which have shown a beneficial effect of such diets on glycaemic control have been short term, using diets with an enormous and impracticable increase in intake of fibre for patients whose diabetes was already well controlled. ${ }^{1314}$ For example, in a pioneering study an increase in fibre from 17.6 to $96.6 \mathrm{~g} /$ day produced a fall in fasting plasma glucose concentration from 6.7 to $5.7 \mathrm{mmol} / 1 .^{15}$

We know of only three other studies in which a high carbohydrate, high fibre diet has been tried in patients with poorly controlled type II diabetes. In Oxford 15 patients with a mid-afternoon blood glucose concentration consistently over $12 \mathrm{mmol} / \mathrm{l}$ receiving high doses of sulphonylureas were recruited, and $11 \mathrm{com}$ pleted the trial. ${ }^{16}$ On their usual diet (fibre $26 \mathrm{~g} /$ day) fasting plasma glucose concentration was $9.6 \mathrm{mmol} / \mathrm{l}$; after six weeks on a low carbohydrate diet (fibre $12 \cdot 7 \mathrm{~g}$ / day) it was $8.4 \mathrm{mmol} / \mathrm{l}$; and after six weeks on a high carbohydrate diet (fibre $67 \cdot 7 \mathrm{~g} /$ day) it was $6.8 \mathrm{mmol} / \mathrm{l}$. In contrast, Coulston et al found their nine patients (mean fasting plasma glucose concentration of 10.8 $\mathrm{mmol} / \mathrm{l}$ ) had a significant deterioration in glycaemic control after only 15 days on a $60 \%$ carbohydrate diet (fibre $38 \mathrm{~g} /$ day), whereas in patients with better control a similar increase in carbohydrate led to a fall in fasting plasma glucose concentrations (from 5.9 to $5.3 \mathrm{mmol} / \mathrm{l}$ ) after four weeks. ${ }^{17}$ In patients similar to those in our study increasing fibre from $11 \mathrm{~g} / 4 \cdot 18 \mathrm{MJ}(1000 \mathrm{kcal})$ to $26.7 \mathrm{~g} / 4 \cdot 18 \mathrm{MJ} /$ day in a high carbohydrate diet had no effect on concentration of lipids or any measure of glycaemic control. ${ }^{18}$

Even if intakes of fibre of 50-100 g/day had an effect in poorly controlled diabetes, it is doubtful whether ordinary people would eat this much fibre for more than a few weeks. ${ }^{19}$ Our patients approved the variety 
of foods on the list they had been given and liked the diet. Their most common sources of fibre were wholemeal bread, breakfast cereals, and baked beans or broad beans, but only two of the 33 patients managed to eat more than $50 \mathrm{~g}$ fibre a day. This finding is similar to those in other studies of outpatients, in which the limits of acceptability for long term diets seem to be taking $45 \%$ of total energy as carbohydrate and $25-35 \mathrm{~g}$ fibre a day..$^{20-24}$ In a large prospective study in the United Kingdom in which patients were advised to take a prudent diet containing about $50 \%$ of energy as carbohydrate and as much fibre as is reasonable from generally available foods the energy intake and the related amount of fibre was a little lower than in our study $(16.9 \mathrm{~g}$ fibre $/ 4.18 \mathrm{MJ}){ }^{24}$ It is difficult to prevent an increased energy intake on a high fibre, high carbohydrate diet without becoming a vegetarian. One study found that increasing fibre intake to $96 \mathrm{~g} /$ day without increasing total energy intake meant taking $42 \%$ of total calories as legumes, ${ }^{15}$ a change which our patients were not prepared to make. Our patients had a modest increase in energy intake (mean $1.35 \mathrm{MJ} /$ day), but this did not lead to weight gain, presumably because it was offset by the deterioration in glycaemic control and loss of glucose in the urine.

The main aim of our study was to see whether increasing the intake of fibre from natural foods would benefit the typical outpatient with type II diabetes who has failed to achieve good control on large doses of sulphonylureas. It did not, and we think the present dietary recommendations for diabetics are unrealistic. When sulphonylureas fail standard advice is that the patient should be changed to insulin. Unfortunately, most evidence that good control is then achieved is anecdotal and from uncontrolled studies. ${ }^{25}$ In a previous prospective randomised crossover study in 58 patients similar to those in this study we found that glycaemic control was improved in only 18 patients when they were given insulin. An additional 22 felt better, of whom only 10 showed better control. ${ }^{4}$ The regimen of once daily Monotard MC in the morning was not ideal, and it has been suggested that a more logical treatment is to correct basal concentrations of plasma glucose with ultralente insulin..$^{26}$

In the present study we found that an evening dose of an average of 36 units of insulin zinc suspension led to noticeable improvement in concentrations of fasting plasma glucose and haemoglobin $A_{1}$, although only a quarter of the patients reached the target haemoglobin $A_{1}$ concentration of $10 \%$. The reason for these disappointing results may be that we used human ultralente insulin, which has an absorption rate (50\% disappearance time) of only 15 hours compared with 44 hours for the bovine equivalent on which the regimen was originally based. ${ }^{28}$ Taking fast acting insulin before meals with a convenient delivery system (Novopen) was well accepted by our patients and led to further improvement ( $\mathrm{a}$ fall in haemoglobin $\mathrm{A}_{1}$ concentration from $11 \cdot 2 \%$ to $9 \cdot 6 \%$ ). Another benefit of insulin was the improvement in fasting concentrations of lipids, though mean serum concentrations of total cholesterol remained well above the optimum level of $5 \cdot 2 \mathrm{mmol} / 1 .^{29}$

Reducing the concentrations of plasma lipids and improving the patient's glycaemic control are desirable goals for the doctor, but the patient may have more subjective aims. The main drawback of insulin treatment is weight gain, which in this study averaged $5 \mathrm{~kg}$ in the patients who took insulin four times daily. Unfortunately, maximum improvement in control will probably be achieved only by a multiple injection regimen; whether this is beneficial in the long term may be answered by the multicentre prospective study of diabetes being carried out in the United Kingdom..$^{30}$

We thank Novo (UK) for financial assistance; Pat Lister, who skilfully typed and retyped the manuscript; Dr Christine Marenah for measuring the lipids, Dr Colin Selby for measuring the $C$ peptides, and Professor K G M M Alberti for his critical and invaluable advice.

1 Charitanski D, Blouquit Y, Papoz L, Soria J, Rosa J, Tchobroutsky G. Controle du diabete non-traité par l'insuline. Nouvelle Presse Médicale 1979;9:585-9.

2 Groop L, Pelkonen R. Treatment failures: a common problem in the management of patients with type II diabetes. Acta Endocrinol [Suppl] (Copenh) 1984;262:131-5.

3 Tattersall RB, Scott AR. When to use insulin in the maturity onset diabetic. Postgrad Med J 1987;63:859-64.

4 Peacock I, Tattersall RB. The difficult choice of treatment for poorly controlled maturity onset diabetes: tablets or insulin? $\mathrm{Br}$ Med $\mathcal{f} 1984 ; 288$ : 1956-9.

5 Nutrition Subcommittee, British Diabetic Association Medical Advisory Committee. Dietary recommendations for diabetics for the 1980s. Hum Nutr Appl Nutr 1982;36:378-94.

6 Committee of the American Diabetes Association on Food and Nutrition. Special report: principles of nutrition and dietary recommendations for Special report: principles of nutrition and dietary recommenda
individuals with diabetes mellitus. Diabetes Care 1979;2:520-3.

7 Mann JI, Lousley S, Peterson D. Difficult choice of treatment for poorly controlled maturity onset diabetes: tablets or insulin. Br Med f 1984; 289:769.

8 Handslip C. Wholefood cooking. London: J Sainsbury, 1986

9 Ambler J, Walker G, Janik B. Measurement of glycosylated hemoglobin on cellulose acetate membrane. Clin Chem 1983;29:340-3.

10 Heding LG. Radioimmunological determination of human C peptide in serum. Diabetologia 1975;11:541-85.

11 Anonymous. Net weight standards for men and women. Stat Bull Metrop Insur Co 1959;40:1-4.

12 Canadian Diabetes Association. Special report: committee guidelines for the nutritional management of diabetes mellitus. Fournal of the Canadian Dietetic Association 1981;42:110-8.

13 Reaven GM. How high the carbohydrate? Diabetologia 1980;19:409-13.

14 Coulston AM, Hollenbeck CB, Swislocki ALM, Chen YDI, Reaven GM. Deleterious metabolic effects of high-carbohydrate sucrose-containing diets Deleterious metabolic effects of high-carbohydrate sucrose-containing diets
in patients with non-insulin dependent diabetes mellitus. Am $\mathcal{M} \mathrm{Med}$ in patients with

15 Simpson HCR, Simpson RW, Lousley S, et al. A high carbohydrate leguminous fibre diet improves all aspects of diabetic control. Lancet $1981 ; 1: 1-5$.

16 Lousley SE, Jones DB, Slaughter P, Carter RD, Jeffs R, Mann JI. High carbohydrate-high fibre diets in poorly controlled diabetics. Diabetic Med 1984;1:21-5.

17 Simpson HCR, Carter RD, Lousley S, Mann JI. Digestible carbohydrate: an independent effect on diabetic control in type 2 (non-insulin-dependent) diabetic patients? Diabetologia 1982;23:235-9.

18 Hollenbeck CB, Coulston AM, Reaven GM. To what extent does increased dietary fibre improve glucose and lipid metabolism in patients with non16-24.

19 Hollenbeck CB, Lecklem JE, Riddle MC, Connor WE. The composition and nutritional adequacy of subject-selected high carbohydrate low fat diets in nutritional adequacy of subject-selected high carbohydrate
insulin-dependent diabetes. Am $\mathcal{f}$ Clin Nutr 1983;38:41-51.

20 Geekie MA, Porteous J, Hockaday TDR, Mann JI. Acceptability of high fibre diets in diabetic patients. Diabetic Med 1986;3:65-8.

21 Stevens J, Burgess MB, Kaiser DL, Sheppa CM. Outpatient management of diabetes mellitus with patient education to increase dietary carbohydrate and fiber. Diabetes Care 1985;8:359-66.

22 Bernard RJ, Lattimore L, Holly R, Cherney S, Pritikin N. Response of noninsulin dependent patients to an intensive program of diet and exercise. Diabetes Care 1982;5:370-4.

23 Kinmouth AL, Angus RM, Jenkins PA, Smith MA, Baum JD. Whole foods and increased dietary fibre improve blood glucose control in diabetic children. Arch Dis Childhood 1982;57:187-94

24 Horrocks PM, Blackmore R, Wright AD. A long-term follow up of dietary advice in maturity-onset diabetes: the experience of one centre in the UK prospective study. Diabetic Med 1987:4:241-4

25 Home $P$. What went wrong? A guide to designing a useful clinical research study before it is too late. Practical Diabetes 1987;4:39-43.

26 Holman RR, Turner RC. Diabetes: the quest for basal normoglycaemia. Lancet 1977; i:469-74.

27 Turner RC, Phillips MA, Ward EA. Ultralente based insulin regimens: clinical applications, advantages and disadvantages. Acta Med Scand 1983;67:75-86. 28 Hilderbrandt $P$, Berger A, Volund A, Kuhl C. The subcutaneous absorption of human and bovine ultralente formulations. Diabetic Med 1985;2:355-9.

29 Shepherd J, Betteridge DJ, Durrington P, et al. Strategies for reducing coronary heart disease and desirable limits for blood lipid concentrations: guidelines of the British Hyperlipidaemia Association. Br Med F 1987;295: $1245-6$

30 Multi-centre study. UK prospective study of therapies of maturity-onset diabetes. I. Effect of diet, sulphonylurea, insulin or biguante therapy on fasting plasma glucose and body weight over one year. Diabetologia 1983;24:404-11.

(Accepted 20 May 1988) 